\title{
Flipping the Career Development and Employment Classroom: Engaging Students to Enhance Learning
}

\author{
Dara V. Chan ${ }^{1}$, Eileen J. Burker ${ }^{1}$ b, Judy A. Schmidt ${ }^{1}$ c \\ 1 The University of North Carolina at Chapel Hill \\ Keywords: flipped classroom, career development, experiential learning \\ https://doi.org/10.52017/001c.24286
}

\section{Rehabilitation Counselors and Educators Journal}

Vol. 10, Issue 1, 2021

\begin{abstract}
While many rehabilitation counselor educators incorporate activities into the classroom, few have embraced the concept of "flipping the classroom," where class time is based around active learning rather than relying on lecture alone. The rise in dual rehabilitation and mental health counseling programs mean more students enroll seeking training in mental health counseling, but may have less interest in traditional rehabilitation and vocational assessment. The flipped classroom offers a means to engage today's students in vocational and career counseling courses, exposing them to fundamentals of rehabilitation and newer models of employment for people with disabilities. This article provides practical recommendations for creating a flipped career development and employment classroom, including specific examples of student-centered learning activities and how to integrate the flipped approach into existing courses.
\end{abstract}

The career development course is one of CACREP's common core curriculum areas required for accredited Clinical Rehabilitation Counseling programs (Council on the Accreditation of Counseling and Related Educational Programs, 2015). However, student interest for the course content is historically low, and they do not consider it relevant for their future careers as counselors (Lara et al., 2011). This disconnect is increasing as the number of students applying to dual mental health and rehabilitation counseling programs express primary interest in clinical counselor training. Shifting from the passive learning of a traditional lecture-based class to active learning formats such as the flipped classroom model can improve student engagement in career development courses and learning outcomes (McLaughlin et al., 2014). While becoming more prevalent in the STEM, business, and humanities curricula, there are also opportunities to embrace the "flipped classroom" approach within health professions and counselor education curriculum (Fulton \& Gonzalez, 2015; Moran \& Milsom, 2015). This paper provides an overview of the flipped classroom, its benefits and critical elements, and discusses why the career development course is ideal for the flipped classroom approach in the rehabilitation counseling curriculum. Specific examples of student-centered learning activities for the course are also shared.

The idea of a flipped classroom has received increasing attention as a way to engage students and foster higher level critical thinking through student-led learning initia- tives in higher education (Gerstein, 2011). As the name implies, instead of students learning content in the classroom through traditional lectures with practice assignments completed later, a flipped classroom has students learn basic concepts at home through pre-class work, then uses the classroom time to actively practice applying, analyzing, or synthesizing what they have learned (Gerstein, 2011; Milman, 2012) (see Figure 1). The idea behind the flipped classroom approach stems from education and cognition research showing students have better gains in learning and retention of new information when engaged in active learning that uses this new knowledge (Bergmann \& Sams, 2012a; Lage et al., 2000; Richardson et al., 2012). Core components of flipped classrooms include (1) exposure to new content before class time, (2) in-class activities or discussion of new materials, and (3) assessment (Brame, 2013; Caffarella \& Daffron, 2013).

\section{Core Components of a Flipped Classroom}

The first component of a flipped classroom, pre-class work and exposure to new content, is typically accessed or delivered through traditional assigned reading material, including textbooks, or more contemporary content delivery through videos, podcasts, PowerPoint lecture with voiceover, or a combination of methods. Similar to developing online classes, modules built into online Learning Management Systems, such as Blackboard and Sakai, can in-

\footnotetext{
a dara_chan@med.unc.edu

b eburker@med.unc.edu

c judy_schmidt@med.unc.edu
} 
clude written segments on each new topic or skill, while lecture capture tools, such as VoiceThread, Camtasia, and echo360, can be used to provide a combination of PowerPoint and audio. When using videos to introduce new content for pre-class learning, it is recommended that content is delivered through shorter 20 to 50 minute video segments that emphasize the critical content, rather than recording a longer lecture in its entirety (Long et al., 2016), or even shorter 10 to 15 minute segments focused on one topic at a time (Bergmann \& Sams, 2012a). Video segments of specific topics can then be re-watched when needed to reinforce learning (UNC Center for Faculty Excellence, n.d.). Research examining video preferences for pre-class learning material noted most students surveyed preferred videos developed by instructors that simulated the classroom learning environment, though videos from alternative sources such as YouTube were also positively rated (Long et al., 2016).

After pre-class learning, the second component of the flipped classroom consists of various in-class activities to reinforce and enhance the students' understanding of new material and increase their ability to apply the knowledge gained (Brame, 2013). In-class student-based learning strategies can include problem solving activities, case studies, peer instruction, peer feedback, group work, role play, videos, debate, and poll-based discussion (Milman, 2012). In-class learning activities encourage reflection and practice, which are critical for adult learning in graduate studies (Caffarella \& Daffron, 2013). Although the focus of class time is no longer spent on lecturing, microlectures of 1 to 3 minutes in length may be used when needed in class following the activities, to recap the process and concepts learned (McLaughlin et al., 2014). The opportunity to practice activities and skills during class time adds the benefit of support from the instructor and peers that may not be available when individual homework is assigned in the traditional classroom model (Brame, 2013). For example, in a redesigned basic pharmaceuticals course, students often participated in "pair and share activities" working with a partner in class to address discussion questions before sharing with the larger group. In addition, each week a group of students was randomly selected to present a summary of the pre-class learning material to the class and answer any questions from their peers on the new material (McLaughlin et al., 2014). Similarly, instead of using class time for lecture followed by working on practice problems for homework, students in a flipped first-year cardiovascular, respiratory, and renal physiology course watched recorded lectures prior to class, completed a brief quiz to check for learning at the beginning of class, and spent the class time working on the practice problems (Tune et al., 2013). The brief quiz to check for learning is an example of the third component of the flipped classroom, assessment.

Brief assessments in a flipped classroom are typically administered through quizzes, worksheets, or short writing assignments completed either immediately following the at home pre-class learning work, just before class, or at the beginning of class (Long et al., 2016). These assessments often serve two purposes: as incentive for completing the pre-class learning and to check for gaps in learning of critical content (Brame, 2013; Tune et al., 2013). As a learning tool for both the instructor and student, these brief as-

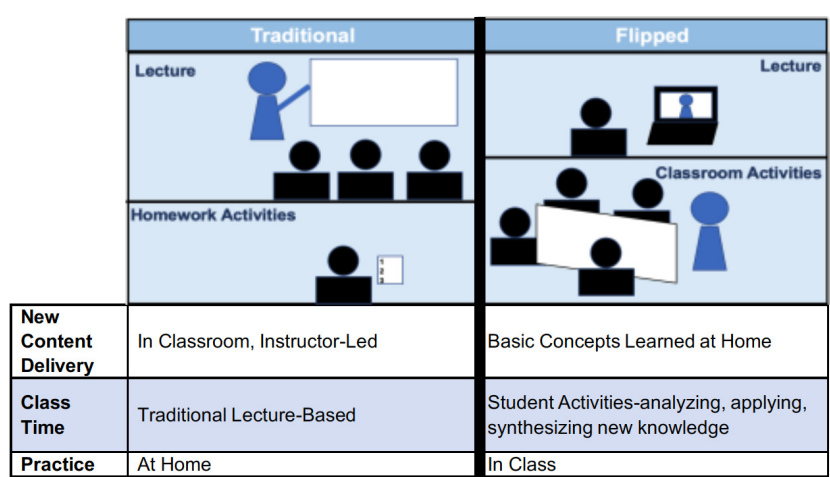

\section{Figure 1. Comparison of Traditional and Flipped} Classroom Models

Note. Adapted with permission from University of Washington - Center for Teaching and Learning (https://teaching.washington.edu/topics/engaging-students-in-learning/flipping-the-classroom/

sessments are valuable in guiding activities and discussion for the class time when gaps in learning are identified. As a check for learning, brief assessments typically have a low point value assigned, and may be administered, collected, and graded at random to maintain the incentive to be prepared for class (Brame, 2013). While a pre-class assessment can be a motivator for completing pre-class work and performing well in class, similar brief assessments can be given at the end of class to test students' grasp of key concepts and skills demonstrated or discussed as part of the in-class activities (McLaughlin et al., 2014).

\section{Benefits of a Flipped Classroom}

In addition to built-in incentives for completing preclass learning and the in-class support from peers and the instructor, benefits of flipping the classroom include the opportunity for immediate feedback for students, increased interaction between faculty and students, increased engagement as a result of in-class activities, and improved learning and academic performance (Brame, 2013; Zainuddin \& Halili, 2016). Research comparing a flipped model classroom with a traditional lecture-based classroom model for the physiology course reported significantly higher test scores for students in the flipped classroom (Tune et al., 2013). Outcomes research also demonstrated increased student motivation, confidence, and competence in material learned (McLaughlin et al., 2014; Tune et al., 2013). In one example, students in a counselor education class who were surveyed regarding the effectiveness of a flipped classroom design to facilitate learning, gave high ratings for in-class activities of working on small group experiential projects, working on assignments during class for immediate instructor feedback, and listening to guest speakers (Moran \& Milsom, 2015). Students in flipped classrooms also report more confidence in their abilities and accountability to complete out of class work. In research comparing course evaluations before and after redesigning a basic pharmaceuticals course, student course evaluations for the flipped classroom design were significantly higher in four main areas: (a) attendance in class; (b) confidence in the ability to apply knowledge and skills developed in the course; (c) the need 
to prepare for the course; and (d) the instructor consistently encouraging active participation in the course (McLaughlin et al., 2014).

For the student, the pre-class material also allows for self-paced, self-directed learning and the opportunity to review content multiple times, while both pre-class and inclass components are able to accommodate multiple student learning styles (McLaughlin et al., 2014; Moran \& Milsom, 2015; Tune et al., 2013; Volpe, 2015). Increased peer interaction and team learning in the flipped classroom also contribute to improved knowledge gains (McLaughlin et al., 2014; Moran \& Milsom, 2015). With increased confidence and competence in materials and skills learned in class, performance on graded assignments improves, which results in faculty spending less time providing written feedback (Moran \& Milsom, 2015). Other benefits for faculty include less time spent lecturing, and the shift to a facilitator role and subject matter expert in the class, rather than lecturer (Tune et al., 2013; Volpe, 2015). With a heavy emphasis on the practical application of vocational assessment tools and developing occupational analysis skills, the career development course presents an opportunity to shift to inclass practice and skill development through a flipped classroom approach to benefit students and faculty alike.

\section{Application for Career Development Courses}

In considering a change in course design, most rehabilitation counselor educators already incorporate some level of a flipped classroom into their courses. It may include replacing lecture time with an in-class activity, video, group work, case study discussion, guest speaker, or site visit. Career theory and career counseling skill development lends itself well to the use of class time on application, problem solving, discussion, and site visits. In research using a flipped format for a career counseling course, students rated the interactive components of the course, consisting of class exercise, skills practice, and peer interaction as the three most important factors in the overall class experience (Fulton \& Gonzalez, 2015). Personal application of career related content such as completing career assessments (e.g., Life Values Inventory, Strong Interest Inventory, Values Card Sort) and practicing structured career interviews was also rated as important to students in the career counseling class (Fulton \& Gonzalez, 2015).

Unfortunately, many students approach the career development course in particular with low motivation and do not consider it as professionally relevant to their future work (Lara et al., 2011), while faculty report considerable effort convincing students of its value (Osborn \& Dames, 2013). In addition, senior faculty report the career development course is the least satisfying course to teach, and as a result it is often assigned to new or non-tenured track faculty (Savickas, 2003). Embracing the flipped classroom model permits movement away from passive, lecture-based learning toward an increased emphasis on student-centered learning activities to increase motivation and confidence in career counseling and vocational skills for the emerging counselor. With the Workforce Investment Opportunity Act's (WIOA) focus on helping people with disabilities find quality jobs in competitive, integrated work settings, and assisting youth with disabilities find careers, not just employment, an emphasis on finding new ways to develop career counseling and vocational assessment skills in current students is critically important. Balancing the importance of developing these fundamental rehabilitation skills with student and faculty disinterest in the career development course, the rehabilitation program at The University of North Carolina at Chapel Hill (UNC-CH) embraced a flipped classroom approach for the Career Development and Employment: Counseling Persons with Disabilities course with a focus on in-class active learning strategies to engage students and enhance confidence in being able to use core vocational rehabilitation skills.

\section{Flipping the Classroom at UNC Chapel Hill}

The Career Development and Employment course at UNC-CH is divided into three main sections. The first section consists of learning career development theory, vocational assessment, occupational analysis, the Dictionary of Occupational Titles (DOT), job analyses, and labor market surveys. The second section introduces different employment models and vocational rehabilitation counselor employment settings, job accommodations and assistive technology, career counseling, and job development. The third section focuses on aspects of community integration that also impact employment and occupation such as transportation, accessibility in the community, housing, and leisure and recreation. The course takes an overall experiential approach of "learning by doing" through in-class activities as a key component of the flipped classroom. Throughout the course, various student-centered learning activities comprise significant portions of the class time, including problem solving and demonstration, peer supported learning, site visits, and guest speakers (Table 1). Each of these activities often serve as both practice using new skills and knowledge, and as pre-work or practice for larger graded assignments due later in the semester. In both cases, students receive immediate feedback from the instructor and/or peers to self-assess additional learning needs or supports. Below, ideas for in-class activities to enhance learning and student engagement in the career development flipped classroom are described related to the major objectives of the course.

\section{Career Development Theory}

For the first section of the course focused on the core components of career development theory, vocational assessment and occupational analysis, students view videos of different career development theories (e.g., Minnesota Theory of Work Adjustment; Tran, 2013) to discuss in class, and complete in-class reflective writing to consider their own career histories and identify a theory that resonates with how they view their own career development. Students also practice administering and interpreting career exploration tools such as Holland's Self-Directed Search and the online $\quad \mathrm{O}$ Net Interest Profiler (https://www.mynextmove.org/explore/ip) to compare findings and discuss as a group any surprise job matches. Students practice career self-awareness activities, such as creating a career timeline or career genogram, and discuss how 
Table 1. Examples of In-Class Learning Opportunities for a Career Development Flipped Classroom

\begin{tabular}{|c|c|c|c|}
\hline \multicolumn{4}{|c|}{ Class Time } \\
\hline In-Class Activities & Site Visits & Guest Speakers & Peer-Supported Learning \\
\hline $\begin{array}{l}\text { - } \text { Practicing career self-aware- } \\
\text { ness activities } \\
\text { ing career exploration tools } \\
\text { (e.g., O*Net Interest Profiler, } \\
\text { Holland Self-Directed } \\
\text { Search) } \\
\text { - Conducting transferrable } \\
\text { skills analyses using soft- } \\
\text { ware such as OASYS } \\
\text { - Identifying jobs in the Dictio- } \\
\text { nary of Occupational Titles } \\
\text { or O*Net based on a descrip- } \\
\text { tion } \\
\text { Developing a labor market } \\
\text { survey script and data work- } \\
\text { sheet } \\
\text { Practice completing a job } \\
\text { analysis through watching } \\
\text { job focused videos } \\
\text { Drafting an accommodations } \\
\text { request letter based on a } \\
\text { case study } \\
\text { Viewing career theory } \\
\text { videos }\end{array}$ & $\begin{array}{l}\text { - Conducting an onsite job } \\
\text { analysis } \\
\text { - Completing a case-based ac- } \\
\text { cessibility analysis at a com- } \\
\text { munity location } \\
\text { - Visiting different employ- } \\
\text { ment-based models } \\
\text { - Psychiatric rehabilitation } \\
\text { (e.g.. Clubhouse model) } \\
\text { - Autism spectrum disorder } \\
\text { - Therapeutic farm } \\
\text { - Traumatic brain injury } \\
\text { clubhouse } \\
\text { - Visiting a One Stop Center } \\
\text { Visiting a Center for Inde- } \\
\text { pendent Living }\end{array}$ & $\begin{array}{l}\text { - Individualized Placement } \\
\text { and Support (IPS) Employ- } \\
\text { ment specialist } \\
\text { - } \quad \text { IPS Peer Support Specialist } \\
\text { - IPS Client } \\
\text { - } \text { Assertive Community Treat- } \\
\text { ment (ACT) team Vocational } \\
\text { Specialist } \\
\text { - } \text { ACT Client } \\
\text { - Vocational Rehabilitation } \\
\text { counselors with varying } \\
\text { caseloads (general, school/ } \\
\text { transition, mental health, } \\
\text { substance use) } \\
\text { - Private Rehabilitation Coun- } \\
\text { selors (Workers Compensa- } \\
\text { tion, Short Term Disability/ } \\
\text { Long Term Disability/Private } \\
\text { Case Management) } \\
\text { Service Animals/Psychiatric } \\
\text { Service Animals }\end{array}$ & $\begin{array}{l}\text { - Identifying job accommoda- } \\
\text { tions and assistive technol- } \\
\text { ogy based on case studies } \\
\text { - Developing job club curricu- } \\
\text { lum, after reviewing exam- } \\
\text { ples } \\
\text { - Preparing an elevator } \\
\text { speech for Job Development } \\
\text { employer contacts, and dis- } \\
\text { cussing different strategies } \\
\text { for approaching different } \\
\text { types of employers } \\
\text { - Identifying apps to help peo- } \\
\text { ple with disabilities obtain or } \\
\text { maintain employment } \\
\text { - Making a game, creating a } \\
\text { video, or demonstrating a } \\
\text { skill } \\
\text { Role playing games }\end{array}$ \\
\hline
\end{tabular}

using these with tools with clients could help facilitate the vocational interview and collaborative goal setting.

\section{Vocational Assessment and Transferrable Skills Analysis (TSA)}

For pre-class learning related to vocational assessments, students first watch video examples of counselor-client interviews, and then bring their resumes to class to pair up with a partner and take turns practicing interviewing each other using a similar structured career interview. Based on the jobs obtained through the peer vocational interviews, the class works through examples together guided by the instructor in using OASYS TSA software to identify job matches. The group then works through problems encountered, such as what information might be needed to distinguish between multiple job matches, why it is important to know details regarding the length of employment for positions to be included in the career profile, and how adjustments to the functional profile affect job matches. Practice completing the interviews and TSA in class prepares students to complete these activities independently for their own job analysis projects working with a person with a disability. Because students gain knowledge from the practice of completing in-person interviews and the TSA, they are more likely to obtain accurate results and achieve better outcomes in the final job analysis project and when working with clients in internship and beyond.

\section{Occupational Analysis}

When learning about the DOT and components of the code, students work in groups to identify DOT titles for a list of unusual occupations (e.g., Christmas elf, smoke jumper, dog walker) using $\mathrm{O}^{*} \mathrm{Net}$ and occupational search software, such as OASYS. Students also return to their own occupational titles identified from the TSA activities to review the levels of Data, People, Things delineated by the code for agreement based on their experience.

\section{Job Analysis}

To learn about job analyses, students first watch videos in class of specific job tasks and practice completing a job analysis worksheet to begin learning what to attend to and how to classify work activities. The following week, students visit the hospital on campus to observe employees in two areas, food services and environmental services. The class is divided into two groups to visit the different areas for approximately 30 minutes and then switch. After a brief tour, students observe an employee in a specific position to identify the functional demands of the job and are given an opportunity to ask questions as they are completing the job analysis worksheet. Immediately following the on-site hospital visit, the groups come back together in class to debrief and discuss the experience, compare results of the job analysis worksheets, brainstorm potential job accommodations, and answer questions. The group also tries to identify the DOT code for the occupation by narrowing down the occupational category and primary tasks. This sets the stage for the students completing a job analysis independently in the community based on a job selected from TSA job matches and vocational assessment results as part of their own job analysis project. 


\section{Labor Market Survey}

Students familiarize themselves with the purpose of a labor market survey (LMS) before class by reading an article by Van de Bittner et al. (2012). The article also includes a sample script to contact employers and an example of a data worksheet to track LMS information obtained through these contacts. Students can then develop their own LMS script and data worksheet in class, or draft emails with similar information to employers and problem solve in pairs who to contact within an organization and how to best reach the person to prepare students to make these contacts on their own for their job analysis project.

\section{Job Accommodations and Assistive Technology}

Another example of peer supported learning through group work in the class includes identifying job accommodations and assistive technology options based on case studies. Students work in teams with cases assigned and are given time to brainstorm and research a number of feasible ideas for accommodations, then share with the class findings of options they would present to the client and employer, the cost for each, and the justification for the one they recommend. Similarly, students work in teams to identify apps as "pocket sized accommodations" to help people with disabilities obtain transportation, improve interviewing and social skills, sequence tasks, regulate anxiety, track and manage symptoms, or keep medication schedules. For a graded project, students build off this work to identify apps that would specifically benefit their job analysis client and have the opportunity to propose their own idea for an app that would be helpful for people with disabilities. Students also learn about the key components of a job accommodation request letter and view samples as part of pre-class activities and spend time in class in small groups drafting an accommodations request letter for a client based on a case study as practice for writing an accommodation request letter for their client in the job analysis project.

\section{Employment Models and Employment Settings}

Guest speakers are invited to class representing different employment models and settings, particularly those where students may find future employment to increase relevance (Moran \& Milsom, 2015). A panel of state/federal vocational rehabilitation counselors from various caseloads, and private rehabilitation counselors from Worker's Compensation or private disability companies are invited to speak to the class, as well as Individualized Placement and Support specialists, and vocational specialists from Assertive Community Treatment teams. When possible, these employment representatives are invited to also bring a client and/or Peer Support Specialist to share their perspective of the activities, challenges, and successes of the employment or return-to-work teams.

Site visits to different employment models for people with disabilities are also completed. As a class, students attend the local clubhouse for people with psychiatric disabilities to see first-hand the "work ordered day" in action with a chance to interview clubhouse members and staff. The class also visits an organization that exclusively em- ploys adults with autism spectrum disorder working within several small business enterprises. Toward the end of the semester, the class visits a therapeutic farm for individuals with psychiatric disabilities that serves as a venue for both respite and skill building activity. Available activities for participants include horticulture therapy, yoga, cooking classes, and working with emotional support dogs and therapeutic chickens. After receiving a tour of the farm and learning about the philosophy of each activity area, students spend the remainder of class time in a pre-arranged service project such as painting, gardening, or building to benefit the farm. Incorporating a service-learning component into the class time through a site visit is recommended as a way to enhance the relevance of career counseling and understanding the centrality of work affecting other areas of life, particularly for people with disabilities (Fulton \& Gonzalez, 2015).

\section{Accessibility Analysis}

Finally, to practice assessing locations for accessibility, the students first review an accessibility analysis measure (e.g., The ADA Checklist for Existing Facilities: https://www.adachecklist.org/) as part of the pre-class work, and then meet for class at a nearby public park. With tape measures in hand, students work in groups to complete The Accessibility Survey, evaluating parking lots, curb cuts, walkways, bathrooms, drinking fountains, and doorways. In addition, each group is given a case study of an individual with specific limitations and future goals. The case may state, "Bob is a 62-year-old with congestive heart failure and chronic obstructive pulmonary disease who is unable to walk long distances or lift over 10 pounds. His low level of activity has led to boredom and depression. His first grandson is going to Disney World this summer and he would like to improve his stamina to be able to go on the trip." The student groups must spend time exploring the site to make recommendations on how the park could help the individual meet the expressed goals, and any potential barriers identified in using the available activities and facilities. In the last portion of the class, students share their results based on the specific case with recommendations on improving accessibility of the park for the individual, and overall. Following this in-class activity, each student selects a recreation-based location in the community to complete a similar accessibility analysis and submits results and recommendations for improving accessibility in an individual paper.

\section{Student Perspectives on the Flipped Classroom}

Qualitative feedback from the mid-course and final evaluations of students since integrating the flipped classroom model in the Career Development and Employment course supports the move to this model to maximize experiential components and application of new knowledge. Comments often centered on using the class time for site visits such as, "The site visits are extremely helpful in seeing the handson work and experiencing it." Students also frequently commented on the benefits of using class time to bring in professionals and clients as speakers to contextualize the learning: "Guest speakers and real-world applications to 
topics have been very interesting and helpful," "Liked hearing personal stories from clients like (IPS client) today,” and "The guest speakers you have coming in have been great! It is awesome to hear from professionals in the field and what their jobs look like on the day-to day terms, much easier to conceptualize than book/PowerPoint descriptions.” Other students commented on multiple aspects of the class they found beneficial, "Guest speakers from people in the fieldI feel like I am starting to really understand new and potential career opportunities. Also the case studies. Sometime it can be hard to understand a process without thinking about how it can apply to an individual," and similarly, "I really enjoy the speakers. They give a personal, experienced perspective that we don't receive from reading alone. I also really enjoy your teaching methods... I also enjoy class activities and case studies." Other students described the confidence gained from the practice activities that enabled them to complete analyses independently. As one student noted, "In my practicum interview I was asked if I had ever completed a job analysis. I could say with confidence that I had!”

There are also aspects of the flipped classroom that students find challenging. Some students noted difficulty with the shift of pre-work learning outside of class, stating "The coursework for this class is very heavy," "So much work based out of class," and "Sometimes the readings for this class take as long as those for all other classes combined." These findings of students feeling the out of class work is too intensive is consistent with the literature. For example, "Too much time required or effort not indicative of course credit" was the most frequent comment regarding the least favorite aspect of the flipped model class for students in a physiology class (Tune et al., 2013). In other cases, students felt using the class time to practice or do pre-work for the larger assignments was more burdensome than helpful, "It is really frustrating in the job analysis project because we did each thing individually (working with partners on the TSA and then going to the hospital to shadow with the worksheet), and now we are having to do it all over again for the $2^{\text {nd }}$ time."

\section{Future Directions}

With the 2014 enactment of WIOA legislation impacting the work process and focus of vocational rehabilitation counselors, many activities available through a flipped classroom can help graduate students hone the skills that they will use in their careers related to this legislation. Creating in-class activities that strengthen flexibility and adaptability, and develop skills for working with students as young as 14 and their families may be particularly important. Additional skills related to WIOA that could be enhanced by team activities include understanding fee schedules, budgeting and collaboration exercises emphasizing cost-sharing between organizations, and group activities based on case studies to determine what supports and services (e.g., assistive technology, job accommodations, job readiness skills, transportation) might be needed. In addition, group assignments applying knowledge of Social Security Insurance/Social Security Disability Insurance (SSI/ SSDI) benefits and work-related incentives using real ex- amples of individuals planning to return to work can be used as problem-based learning activities related to benefits counseling. Opportunities for using class time for role play to practice relationship building, advocacy, and negotiation skills prior to entering practicum can also build student confidence.

\section{Further Considerations}

While there are many benefits to students and faculty in switching to a flipped classroom format, there are also risks that must be noted. First, flipping the classroom departs from the class time being structured and accounted for, meaning there is a certain level of unpredictability and relinquishing control over the class time and content covered (Volpe, 2015). This requires flexibility to adapt the class on any particular day to what material or skills may need to be addressed as a result of the initial assessment. Having back-up plans for many different activities and content assessment areas can be difficult for faculty. Second, students must take responsibility for their own learning (Moran \& Milsom, 2015). Although this may be said for any course format, the flipped classroom directly places the responsibility for initially learning critical concepts in the hands of the students. If students do not complete the pre-work required of the flipped classroom model to learn basic concepts and new material to successfully engage in the inclass learning activities and practice, they will likely fall behind. Finally, while time is saved in preparing and delivering lectures, similar to online courses, it does require an investment of time up front in planning and preparing for the course overall (Volpe, 2015).

\section{Recommendations}

Making the change to revamp a course to a flipped classroom format requires time and planning to develop preclass learning materials, plan in-class activities, and create assessments. Recommendations for faculty include starting small, focusing on one course at a time (such as the career development course), and incorporating one new activity each semester (McLaughlin et al., 2014). For faculty interested in pursuing more dramatic change or adopting the flipped format, some questions to consider to facilitate this process include: (1) What in-class activities could be added or enhanced to move the course along the continuum toward a flipped classroom?; (2) What lecture content can best be understood through alternative assignments or through electronic formats, such as recorded lectures?; (3) What opportunities exist to integrate peer instruction and peer feedback into the curriculum?; (4) Are there pieces of large projects or papers that could be worked on in class, as practice, that would allow for instructor or peer feedback prior to completing the assignment?; and (5) What activities would students find helpful to accomplish in this format? (UNC Center for Faculty Excellence, n.d.)

As previously noted, most rehabilitation counseling faculty already incorporate elements of the flipped classroom into the career development and employment course by way of in-class activities. If a complete change to a flipped structure is not possible, consider expanding the time devoted to these practical and problem-based activities and experi- 
ment in a few classes by changing the role from instructor to facilitator to test new methods and gauge student response. In all cases, communicate clearly in the syllabus and throughout the course the reason for choosing the flipped classroom model and the goals of the approach, including a more interactive use of classroom time, more student engagement, more instructor and peer support, and more practice in skill building (McLaughlin et al., 2014). Sharing an article with support for the benefits of a flipped classroom at the beginning of the course can also help persuade students who may be more comfortable with the traditional lecture format and wary of change (Volpe, 2015). It is also helpful to solicit feedback from students regarding the course and structure during the semester (UNC Center for Faculty Excellence, n.d.).

Resources are available to assist with redesigning a course to a flipped classroom mode. Online resources include helpful articles and videos, ranging from, "How to Make Videos Your Students Will Love” (Bergmann \& Sams, 2012 b) to how to use lecture capture technology (e.g., Ohio State IT, 2013). In addition, a university's faculty teaching support center (such as UNC's Center for Faculty Excellence, Cornell University's Center for Teaching Excellence, and Boston University's Center for Excellence in Innovation and Teaching) typically offers resources to help with course redesign setup, technological support, consulting on ideas for how to modify the current curriculum and projects to the flipped format, and even opportunities to shadow an existing flipped classroom on campus.

\section{Conclusions}

There is a need to rethink the design of the career development course in rehabilitation counseling curriculum to increase student engagement and motivation and improve overall skills to assist people with disabilities seeking employment. The flipped classroom offers a promising approach that accommodates different student learning styles and allows outside exposure to new material with the chance to reflect, practice, and engage in problem-based learning facilitated by the instructor, and in collaboration with peers (Tune et al., 2013). The current paper presented opportunities to use class time for experiential learning in the field, such as conducting an onsite job analysis, completing a case-based accessibility analysis at a location in the community, and visiting different employment-based models. In-class activities and peer supported learning related to career development theory, vocational assessment, TSA, and job accommodations allow for practice and problem solving prior to using skills in a real world setting to improve confidence and work quality. Guest speakers and clients from different employment models and organizations, particularly those where students may find future employment, increase the relevance of the content learned (Moran \& Milsom, 2015), and as noted by our student feedback, can expand students' views of career opportunities. With personal application and experiential learning as primary components of the classroom design, the flipped career development class can improve students' perception of the relevance of career development training and increase confidence in using career counseling skills (Fulton \& Gonzalez, 2015; Lara et al., 2011).

Flipping the classroom means putting core rehabilitation counseling principles of person/student-centered learning, individualized attention, peer support, self-determination, and a flexible environment into practice in our career development and employment classrooms. This shift is associated with improved engagement, motivation, academic outcomes, and most importantly, confidence and competence in skill building for counselor education and health professions. Improving career counseling skills for our future counselors has important implications for consumer employment outcomes. Flipping the classroom has the potential to enhance the skills of our graduate students and future rehabilitation counselors so they can help to maximize the vocational outcomes of people with disabilities. 


\section{REFERENCES}

Bergmann, J., \& Sams, A. (2012a). Flip your classroom: Reach every student in every class every day. Internal Society for Technology in Education.

Bergmann, J., \& Sams, A. (2012b, May). How to make videos your students will love. eSchool News. https://w ww.eschoolnews.com/2012/05/21/how-to-make-vide os-your-students-will-love/

Brame, C. (2013). Flipping the classroom. Vanderbilt University Center for Teaching. http://cft.vanderbilt.e du/guides-subpages/flipping-the-classroom/

Caffarella, R. S., \& Daffron, S. R. (2013). Planning programs for adult learners: A practical guide (3rd ed.). Jossey-Bass.

Council on the Accreditation of Counseling and Related Educational Programs. (2015). 2016 CACREP standards. http://www.cacrep.org/wp-content/upload s/2018/05/2016-Standards-with-Glossary-5.3.2018.pd $\mathrm{f}$

Fulton, C., \& Gonzalez, L. (2015). Making career counseling relevant: Enhancing experiential learning using a "flipped" course design. The Journal of Counselor Preparation and Supervision, 7(2). https://do i.org/10.7729/72.1126

Gerstein, J. (2011). The flipped classroom model: A full picture. https://usergeneratededucation.wordpress.co m/2011/06/13/the-flipped-classroom-model-a-full-pi cture/

Lage, M. J., Platt, G. J., \& Treglia, M. (2000). Inverting the classroom: A gateway to creating an inclusive learning environment. The Journal of Economic Education, 31(1), 30-43. https://doi.org/10.2307/1183 $\underline{338}$

Lara, T. M., Kline, W. B., \& Paulson, D. (2011). Attitudes regarding career counseling: Perceptions, and experiences of counselors in training. Career Development Quarterly, 59(5), 428-440. https://doi.or $\mathrm{g} / 10.1002 / \mathrm{j} .2161-0045.2011 . t b 00969 . \mathrm{x}$

Long, T., Logan, J., \& Waugh, M. (2016). Student's perceptions of the value of using videos as a pre-class learning experience in the flipped classroom. TechTrends, 60(3), 245-252. https://doi.org/10.1007/s 11528-016-0045-4

McLaughlin, J. E., Roth, M. T., Glatt, D. M., Gharkholonarehe, N., Davidson, C. A., Griffin, L. M., Esserman, D. A., \& Mumper, R. J. (2014). The flipped classroom: A course redesign to foster learning and engagement in a health profession school. Academic Medicine, 89(2), 236-243. https://doi.org/10.1097/ac $\underline{\mathrm{m} .0000000000000086}$
Milman, N. B. (2012). The flipped classroom strategy: What is it and how can it best be used? Distance Learning, 9(3), 85-87. https://campusadvisories.gwu.e du/sites/g/files/zaxdzs2891/f/downloads/milman-flip ped-classroom edit.pdf

Moran, K., \& Milsom, A. (2015). The flipped classroom in counselor education. Counselor Education and Supervision, 54(1), 32-43. https://doi.org/10.1002/j.15 56-6978.2015.00068.x

Ohio State IT. (2013, February 27). How to use explain everything for lecture capture on the iPad [Video]. YouTube. https://www.youtube.com/watch?v=Za3neQ p17fY

Osborn, D. S., \& Dames, L. S. (2013). Teaching graduate career classes: A national survey of career instructors. Counselor Education and Supervision, 52(4), 297-310. https://doi.org/10.1002/j.1556-6978.2013.00044.x

Richardson, M., Abraham, C., \& Bond, R. (2012). Psychological correlates of university students' academic performance: A systematic review and meta-analysis. Psychological Bulletin, 138(2), 353-387. https://doi.org/10.1037/a0026838

Savickas, M. L. (2003). Advancing the career counseling profession: Objectives and strategies for the next decade. The Career Development Quarterly, 52(1), 87-96. https://doi.org/10.1002/j.2161-0045.2003.tb00 631.x

Tran, J. [jtranz]. (2013, June 27). Theory of work adjustment [Video]. YouTube. https://www.youtube.co $\mathrm{m} /$ watch? $=$ BNuD1AAH4PA

Tune, J. D., Sturek, M., \& Basile, D. P. (2013). Flipped classroom model improves graduate student performance in cardiovascular, respiratory, and renal physiology. AJP: Advances in Physiology Education, 37(4), 316-320. https://doi.org/10.1152/advan.0009 1.2013

UNC Center for Faculty Excellence. (n.d.). Introduction to flipping your class. https://cfe.unc.edu/teaching-and-1 earning/introduction-flipping-class/

Van de Bittner, S., Toyofuku, M., \& Mohebbi, A. (2012). Labor market survey methodology and applications. Rehabilitation Professional, 20(2), 119-136. https://reh abpro.org/page/rehabpro_20_pre

Volpe, D. (2015). Flipping your classroom. American Nurse Today, 10(5), 50-51. https://www.myamericann urse.com/wp-content/uploads/2015/04/ant5-Educatio n-Section_classroom.pdf

Zainuddin, Z., \& Halili, S. H. (2016). Flipped classroom research and trends from different fields of study. International Review of Research in Open and Distributed Learning, 17(3), 313-340. https://doi.org/1 0.19173/irrodl.v17i3.2274 